\title{
Diyabetik Hastalarda COVID-19 İnfeksiyonunun Klinik Seyrini Öngören Faktörler
}

\section{Factors Predicting the Clinical Course of COVID-19 Infection in Diabetic Patients}

\author{
Pınar ȘEN (IID), Tuna DEMIRDAL (IID)
}

İzmir Katip Çelebi Üniversitesi Atatürk Eg̃itim ve Araștırma Hastanesi, İnfeksiyon Hastalıkları ve Klinik Mikrobiyoloji Kliniği, İzmir, Türkiye

Makale atıfı: Şen P, Demirdal T. Diyabetik hastalarda COVID-19 infeksiyonunun klinik seyrini öngören faktörler. FLORA 2021;26(4):639-45.

\section{ÖZ}

Giriş: Diyabeti olan hastalarda yeni koronavirüs hastalığı (COVID-19) infeksiyonunun şiddetli hastalık gelişimi için yatkınlık yarattığı bildirilmektedir. Çalışmamızda COVID-19 infeksiyonu nedeniyle hastaneye yatıılan diyabetik hastalarda yoğun bakıma yatışı ve mortaliteyi etkileyen faktörleri belirlemeyi amaçladık.

Materyal ve Metod: Hastanemizde 1 Mayıs 2020-1 Ağustos 2020 tarihleri arasında COVID-19 infeksiyonu nedeniyle servise yatırılarak izlenen diyabetik hastaların verileri geriye dönük olarak değerlendirildi. Takibinde yoğun bakıma yatırılan ya da ölen hastalar çalıșma grubu, serviste takibi devam eden ve sağ kalan hastalar ise kontrol grubu olarak alındı. Hastaneye yatış anında elde edilen veriler istatistiksel olarak değerlendirildi.

Bulgular: Çalışmaya 83 hasta dahil edildi. Hastaların 41 (\%49.4)'i erkekti ve ortalama yaş $63 \pm 12$ yıl idi. Servis izleminde 28 (\%33.7) hasta yoğun bakıma alındı. Hastane yatışı sırasında öksürük şikayeti olmayan ve nefes darlı̆ı olan hastalarda yoğun bakıma yatış oranı daha yüksek bulundu ( $(p=0.013$ ve $p=0.001)$. Laboratuvar değerlerinden glukoz $(p=0.031)$, aspartat aminotransferaz $(A S T)(p=0.035), C$-reaktif protein (CRP) $(p<0.001)$, prokalsitonin $(p=0.004)$, nötrofil $(p=0.010)$, lenfosit $(p=0.002)$, hemoglobin $(p=0.042)$, ferritin $(p=0.006)$, protrombin zamanı (PT) $(p<0.001)$, INR $(p<0.001)$ ve $D$-dimer $(p=0.038)$ düzeyleri yoğun bakıma yatan hastalarda anlamlı parametreler olarak saptandı. Çalışmaya alınan tüm diyabetik hastaların 22 (\%26.5)'si hayatını kaybetti. Hastane başvurusu sırasında nefes darlı̆ı olan hastalarda ölüm oranı daha yüksek saptandı $(p<0.001)$. Laboratuvar değerlerinden AST $(p=0.041)$, kreatinin $(p=0.037), C R P(p<$ $0.001)$, prokalsitonin $(p<0.001)$, lökosit $(p=0.033)$, nötrofil $(p=0.002)$, lenfosit $(p=0.002)$, hemoglobin $(p=0.006)$, troponin $(p=0.006)$, $D$-dimer $(p=0.034)$, ferritin $(p=0.032), P T(p<0.001)$ ve INR $(p<0.001)$ düzeyleri ölen hastalarda anlamlı parametreler olarak saptandı.

Sonuç: Hastane başvurusu sırasında öksürük olmaması, nefes darlığı varlığı ve hematolojik parametreler, diyabeti olan COVID-19'lu hastalarda ağır klinik seyir için erken dönemde uyarıcı olabilir.

Anahtar Kelimeler: COVID-19; Diyabet; Yoğun bakım; Mortalite 


\title{
ABSTRACT \\ Factors Predicting the Clinical Course of COVID-19 Infection in Diabetic Patients
}

\author{
PInar ȘEN, Tuna DEMIRDAL
}

Clinic of Infectious Diseases and Clinical Microbiology, İzmir Katip Çelebi University Atatürk Training and Research Hospital, İzmir, Turkey

Introduction: It has been reported that new coronavirus disease (COVID-19) infection predisposes to severe disease in diabetic patients. In our study, it was aimed to determine the factors affecting intensive care unit admission and mortality in hospitalized diabetic patients due to COVID-19 infection.

Materials and Methods: The data of diabetic patients who were hospitalized due to COVID-19 infection in our hospital between 1 May 2020 and 1 August 2020 were evaluated retrospectively. Patients who were admitted to the intensive care unit or died were accepted as the study group, and patients who were followed up in inpatient settings and survived as the control group. The data obtained at the time of hospitalization were evaluated statistically.

Results: A total of 83 patients were included in the study. Of these patients, 41 (49.4\%) of them were males and mean age was $63 \pm 12$ years. During follow-up, 28 (33.7\%) patients were admitted to the intensive care unit. Patients who did not have cough and had dyspnea were found to have a higher admission rates to the intensive care unit $(p=0.013$ and $p=0.001)$. Glucose $(p=0.031)$, aspartate aminotransferase (AST) $(p=0.035), C$-reactive protein $(C R P)(p<0.001)$, procalcitonin $(p=0.004)$, neutrophils $(p=0.010)$, lymphocytes $(p=0.002)$, hemoglobin $(p=0.042)$, ferritin $(p=0.006)$, prothrombin time $(P T)(p<0.001)$, INR $(p<0.001)$, and $D$-dimer $(p=0.038)$ levels were found to be significant parameters in patients admitted to the intensive care unit. Twenty-two (26.5\%) of the patients included in the study died. Mortality rate was higher in patients with dyspnea $(p<0.001)$. Laboratory values including AST $(p=0.041)$, serum creatinine $(p=0.037), \operatorname{CRP}(p<0.001)$, procalcitonin $(p<0.001)$, leukocyte $(p=0.033)$, neutrophil $(p=0.002)$, lymphocyte $(p=0.002)$, hemoglobin $(p=0.006)$, troponin $(p=0.006)$, $D$-dimer $(p=0.034)$, ferritin $(p=0.032), P T(p<0.001)$, and INR $(p<0.001)$ levels were found to be significant parameters in diabetic patients who died.

Conclusion: Absence of cough, presence of dyspnea and hematological parameters during hospital admission may be used as early warning signs for severe clinical course in diabetic patients with COVID-19.

Key Words: COVID-19; Diabetes; Intensive care; Mortality

\section{GíRiș}

Ciddi akut solunum sendromu koronavirüs-2 (SARS-CoV-2) etkeninin neden olduğu koronavirüs hastalığı 2019 (COVID-19)'un hastalık yükü küresel olarak sürekli artmaktadır $^{[1]}$. COVID-19 pandemisinde elde edilen klinik ve epidemiyolojik verilere göre hipertansiyon, kardiyovasküler hastaliklar ve diyabet gibi komorbiditeler varlığında ağır infeksiyon görülme oranı yükselmektedir ${ }^{[1]}$.

Uzun süredir devam eden bir diğer küresel salgın, 2019'da 463 milyon yetiskini etkilediği bildirilen ve bu yaș grubundaki dünya nüfusunun \%9.3'ünü olușturan diyabettir ${ }^{[2]}$. Diyabetik hastalarda, doğal ve hümoral immün yanıtın baskılanması nedeniyle bazı bulașıcı hastalıklara karș1 duyarlılığın arttığı belirtilmektedir ${ }^{[3]}$. Diyabet hastaları, hastanede yatan COVID-19 hastalar1- nın önemli bir bölümünü olușturur ${ }^{[4]}$. Hastanede yatan COVID-19 hastalarında diyabet prevalansı İtalya'da \%10'u bulurken, Cin'den yapilan calısmalarda \%20'ye kadar ulaștığı bildirilmiștirir ${ }^{[5,6]}$. $\mathrm{Bu}$ verilere dayanarak diyabet hastalarının SARSCoV-2 infeksiyonu için yüksek bir duyarll1ık sergilediği görülmektedir. Ayrıca, SARS $\mathrm{CoV}-2$ ile infekte diyabet hastalarının klinik gidișinin daha kötü seyrettiği, yoğun bakım ihtiyacı ve ölüm açısından daha yüksek risk altında olduğu belirtilmektedir ${ }^{[4,7]}$. COVID-19 infeksiyonunda diyabetli bireylerin \%22-31 arasında değisen ölüm oranına sahip olduğu bildirilmiștir ${ }^{[8]}$. Diyabet prevalansinın yüksek olması nedeniyle, diyabetli kișilerde COVID-19 infeksiyonunun seyrini tahmin etmek önem arz etmektedir. COVID-19 infeksiyonunda diyabet ile klinik ve laboratuvar bulgularını arasındaki ilișkinin incelendiği çalıșmalar mevcut ol- 
makla birlikte, ülkemizden yapılmıs diyabetik hasta grubunda ağır seyirli infeksiyonu öngören faktörlerle ilgili kısıtlı sayıda çalıșma bulunmaktadır. Diyabetik hasta grubunda yoğun bakıma yatıșı ve mortaliteyi belirleyen klinik faktörlerin belirlenmesi, bu hasta grubunda COVID-19 ile mücadele için geliștirilecek stratejiler açısından gereklidir. Calıșmamizda COVID-19 infeksiyonu nedeniyle hastaneye yatırılarak izlenen diyabetik hastalarda yoğun bakıma yatıșı ve mortaliteyi etkileyen faktörleri belirlemeyi amaçladık.

\section{MATERYAL ve METOD}

İzmir Katip Çelebi Üniversitesi Atatürk Eğitim ve Araștırma Hastanesine 1 Mayıs 2020 - 1 Ağustos 2020 tarihleri arasında bașuran ve COVID-19 infeksiyonu nedeniyle servise yatırılarak izlenen diyabetik hastaların demografik, klinik ve laboratuvar verileri geriye dönük olarak değerlendirildi. Calıșmamız T.C. Sağlık Bakanlığı COVID-19 Bilimsel Araștırma Değerlendirme Komisyonu tarafından onaylandı ve etik kurul izni İzmir Katip Çelebi Üniversitesi Girișimsel Olmayan Klinik Araștırmalar Etik Kurulu'ndan alındı. Tüm hastaların takibi, tedavisi ve yoğun bakıma alınma endikasyonu calıșma periyodu içinde güncel olan TC Sağlık Bakanlığı COVID-19 Rehberi'ne göre belirlendi $^{[9]}$. Ayaktan takip edilen hastalar, 18 yașın altında olan hastalar, diyabet tanısı olmayan hastalar, reverse transkripsiyon-polimeraz zincir reaksiyonu (RT-PCR) testi sonucu SARS-CoV-2 RNA'sı negatif saptanan hastalar, hastane izlemi sırasında takipten clkan hastalar ve COVID-19 dıșında infeksiyon hastalığı süphesi olan hastalar calıșmaya alınmadı. Hastaların demografik verileri, hastaneye bașvurdukları güne ait klinik bulguları, laboratuvar sonucları ve takip bulguları kaydedildi. Hastane yatıșı sırasında yoğun bakıma yatırılan ya da ölen diyabetik hastalar çalıșma grubu, serviste takibi devam eden ya da sağ kalan diyabetik hastalar ise kontrol grubu olarak alındı. Calıșmaya alınan hastaların hastane yatıșının ilk gününde elde edilen laboratuvar verileri değerlendirildi. Elde edilen veriler COVID-19 infeksiyonu olan diyabetik hastalarda yoğun bakıma yatıșı ve mortaliteyi öngörme açısından istatistiksel olarak değerlendirildi.

Calıșmada elde edilen verilerin değerlendirilmesinde IBM SPSS version 22.0 yazılım programı
(Statistical Package for the Social Science; IBM Corp, Armonk, NY, USA) kullanıldı. Değișkenlerin normal dağılım kontrolü Shapiro-Wilk testi ile belirlendi. Tanımlayıcı analiz sonuçarı normal dağılan değișkenler için ortalama ve standart sapma, normal dağılmayan değișkenler için medyan ve \%25-75 yüzdelikler olarak verildi. Calıșma ve kontrol grupları arasında normal dağılım gösteren sürekli değișkenler için Student-t testi, normal dağılıma uymayan değișkenler için Mann-Whitney $\mathrm{U}$ testi, kategorik değișkenler için Ki-kare ve Fisher'in kesin ki-kare testi kullanıldı. İstatistiksel olarak P değeri 0.05'ten küçük olması anlamlı kabul edildi.

\section{BULGULAR}

Calıșmaya 83 hasta dahil edildi. Hastaların 41 (\%49.4)'i erkekti ve ortalama yas $63 \pm$ 12 yıl idi. Hastaların 33 (\%39.8)'ünde hipertansiyon, 18 (\%21.7)'inde kronik kalp hastallğı, 13 (\%15.7)'ünde kronik akciğer hastalığı, 10 (\%12)'unda kronik böbrek yetmezliği, 2 (\%2.4)'sinde malignite ve 2 (\%2.4)'sinde serebrovasküler hastalık bulunmaktaydi.

Hastaneye yatı̣ sirasında var olan bulgular değerlendirildiğinde; 17 (\%20.5) hastada ates, 30 (\%36.1) hastada öksürük, 10 (\%12) hastada kas ağrısı, 22 (\%26.5) hastada nefes darlığı ve 4 (\%4.8) hastada ishal bulunmaktayd.

Tüm hastaların \%10.8 (9/83)'inde lökopeni $(<4$ K/uL), \%7.2 (16/83)'sinde lökositoz (>11 K/uL), \%33.7 (28/83)'sinde anemi (kadinlarda $12 \mathrm{~g} / \mathrm{dL}$, erkeklerde $13 \mathrm{~g} / \mathrm{dL}$ altı), \%13.2 (11/83)'sinde trombositopeni $(<150 \mathrm{~K} / \mathrm{uL}), \% 30.6$ (11/36)'sinda troponin yüksekliği (>0.02 ng/mL), \%79.3 (65/82)'ünde C-reaktif protein (CRP) yüksekliği (>10 mg/L), \%20 (8/40)'sinde prokalsitonin yüksekliği ( $>0.5 \mathrm{ng} / \mathrm{mL})$ mevcuttu. Ferritin düzeyi $500 \mathrm{ng} / \mathrm{mL}$ üstünde olan hasta oranı \%23.5 (4/17) iken D-dimer düzeyi $1000 \mathrm{ng} / \mathrm{mL}$ üstünde bulunan hasta oranı \%10 (4/40) idi.

\section{Yoğun Bakıma Yatıș}

Servis izleminde 28 (\%33.7) hasta yoğun bakıma alındı. Hastane yatıșı sırasında öksürük ve nefes darlığı olan hastalarda yoğun bakıma yatıs oranı daha yüksek bulundu $(p=0.013$ ve $p=0.001)$. Laboratuvar değerlerinden glukoz $(p=$ $0.031)$, AST $(p=0.035)$, CRP $(p<0.001)$, pro- 
kalsitonin $(p=0.004)$, nötrofil $(p=0.010)$, lenfosit $(p=0.002)$, hemoglobin $(p=0.042)$, ferritin $(p=$ $0.006)$, PT $(p<0.001)$, INR ( $p<0.001)$ ve $\mathrm{D}-\mathrm{di}-$ mer $(p=0.038)$ düzeyleri yoğun bakıma yatan hastalarda anlamlı parametreler olarak saptandı (Tablo 1).

Yas, cinsiyet, diğer kronik hastalıkların varlığ1 (kronik böbrek yetmezliği, kronik kalp hastalığı, hipertansiyon, malignite, kronik akciğer hastalığ1, serebrovasküler hastalık), ates, kas ağrısı ve ishal bulgularının varlığı yoğun bakıma yatıs açısından anlamlı risk faktörleri olarak saptanmadı $(\mathrm{p}>0.05)$ (Tablo 1).

\section{Prognoz}

Calıșmaya alınan tüm hastaların 22 (\%26.5)'si kaybedildi. Hastane bassurusu sırasında nefes darlığı olan hastalarda ölüm oranı daha yüksek saptandı $(p<0.001)$ (Tablo 1). Laboratuvar değerlerinden AST $(p=0.041)$, kreatinin $(p=0.037)$, CRP $(p<0.001)$, prokalsitonin $(p<0.001)$, lökosit $(p=0.033)$, nötrofil $(p=0.002)$, lenfosit $(p=$ 0.002), hemoglobin $(p=0.006)$, troponin $(p=$ $0.006)$, D-dimer $(p=0.034)$, ferritin $(p=0.032)$, PT $(p<0.001)$ ve INR $(p<0.001)$ düzeyleri ölen hastalarda anlamlı parametreler olarak saptandı (Tablo 1).

Yas, cinsiyet, diğer kronik hastalıkların varlığ1 (kronik böbrek yetmezliği, kronik kalp hastalığı, hipertansiyon, malignite, kronik akciğer hastalığı, serebrovasküler hastalık), ates, öksürük, kas ağrısı ve ishal bulgularının varlığı ölümü öngörme açısından anlamlı risk faktörleri olarak saptanmadı $(\mathrm{p}>$ 0.05) (Tablo 1).

\section{TARTIȘMA}

COVID-19 pandemisi, haftalar içinde tüm dünyayi etkisi altına alarak bugüne kadar 170 milyondan fazla infekte vakaya ve 4 milyona yakın ölüme sebep olmustur ${ }^{[10]}$. Genel mortalite oran1 düsüuk olmasına rağmen, diyabet hastalı̆̆ı COVID-19 hastalarında ağır hastalık, akut solunum sıkıntısı sendromu ve artan mortalite ile ilișkili bir komorbidite olarak ortaya cıkmıștır ${ }^{[8,10]}$. Hatta yașa göre düzeltilmiș risk hesaplamalarından sonra bile COVID-19 infeksiyonunda yoğun bakım ünitesine yatıs, mekanik ventilasyon ihtiyac1 ve ölümün bağımsız bir öngördürücüsü olarak ortaya $c_{1 k} k_{1} \iota_{\text {tır }}{ }^{[11]}$. Tüm dünyada ölüm oranının orta- lama \%2.1 olarak bildirildiği genel popülasyona kıyasla, diyabetik hastalarda COVID-19 infeksiyonuna bağlı ölüm oranının \%30'u bulabildiği bildirilmistir $^{[8]}$. Calıșmamızda da COVID-19 ile infekte yaklașı her üc diyabetik hastadan biri yoğun bakım izlemine alınmıs olup tüm diyabetik hastaların dörtte birinden fazlasında ölüm saptanmıștır. Farklı merkezlerden bildirilen yüksek oranlar, calısmamı ile de desteklenmiș olup, diyabetik hastalarda COVID-19 infeksiyonunda potansiyel risk faktörlerinin belirlenerek bu hasta grubuna daha titiz bir yakla\$ım sergilemenin gerekliliğini göstermektedir.

Diyabet varlığının, Th1 hücresi ve Th2 hücresi aracilığıla $\mathrm{CD} 4+\mathrm{T}$ hücrelerinin farklılașmasına yol açabileceği ve pro-inflamatuvar/anti-inflamatuvar dengeyi etkileyen $T$ hücrelerinin ișlev bozukluğunu indükleyerek pro-inflamatuvar sitokinlerin salgilanmasında artıs olabileceği belirtilmektedir ${ }^{[12]}$. Ayrıca, COVID-19'un hem pankreas hücrelerinde yer alan ACE-2 reseptörleri üzerinden hem de tedavide kullanılan steroidin etkisiyle glukoz metabolizmasını etkileyerek diyabetik hastalarda infeksiyona bağl bozulabilen kan sekeri düzeninin daha da bozulmasına sebep olduğu düșünülmektedir ${ }^{[13]}$. Hiperglisemi sebebiyle artan glikozilasyon, immün globülinlerde fonksiyon bozukluğuna neden olarak kontrol edilemeyen infeksiyon tablosuna neden olabilir ${ }^{[13]}$. Belirtilen immünolojik bozuklukların diyabetli hastalarda COVID-19 infeksiyonunda ilerleyici sistemik hasar ile ilișkili olabileceği düșünülmektedir ${ }^{[14]}$. Bu hipotezleri destekler sekilde, COVID-19 infeksiyonu olan diyabetik hastalarda ağır pnömoninin daha sık görüldüğü, bu klinik tablonun akut solunum sıkıntısı sendromuna ve septik soka yol açabilen akciğer hasarına neden olduğu gösterilmiștir ${ }^{[14]}$. Diyabetik hastalarda artmıs inflamasyon ve buna bağlı akciğer fonksiyonunda bozukluk, calıșmamızda da gösterdiğimiz sekilde izleminde yoğun bakıma alınan ya da ölen hastalarda nefes darlığı görülme oranının daha fazla olmasını açıklayabilir.

COVID-19 hastalığında diyabet, hipertansiyon, immünsüpresif durumlar, kronik akciğer hastalıkları, kronik kardiyak hastalık, kronik karaciğer ve böbrek hastalığının COVID-19 infeksiyonunda ağır hastalık ve mortalite oranlarında artıș ile ilișkili olduğu bildirilmiștir ${ }^{[10,15]}$. COVID-19 pandemisinde birçok bilinmeyen olduğu gibi, diyabetik hasta grubunda kronik hastalıkların COVID-19 seyrin- 


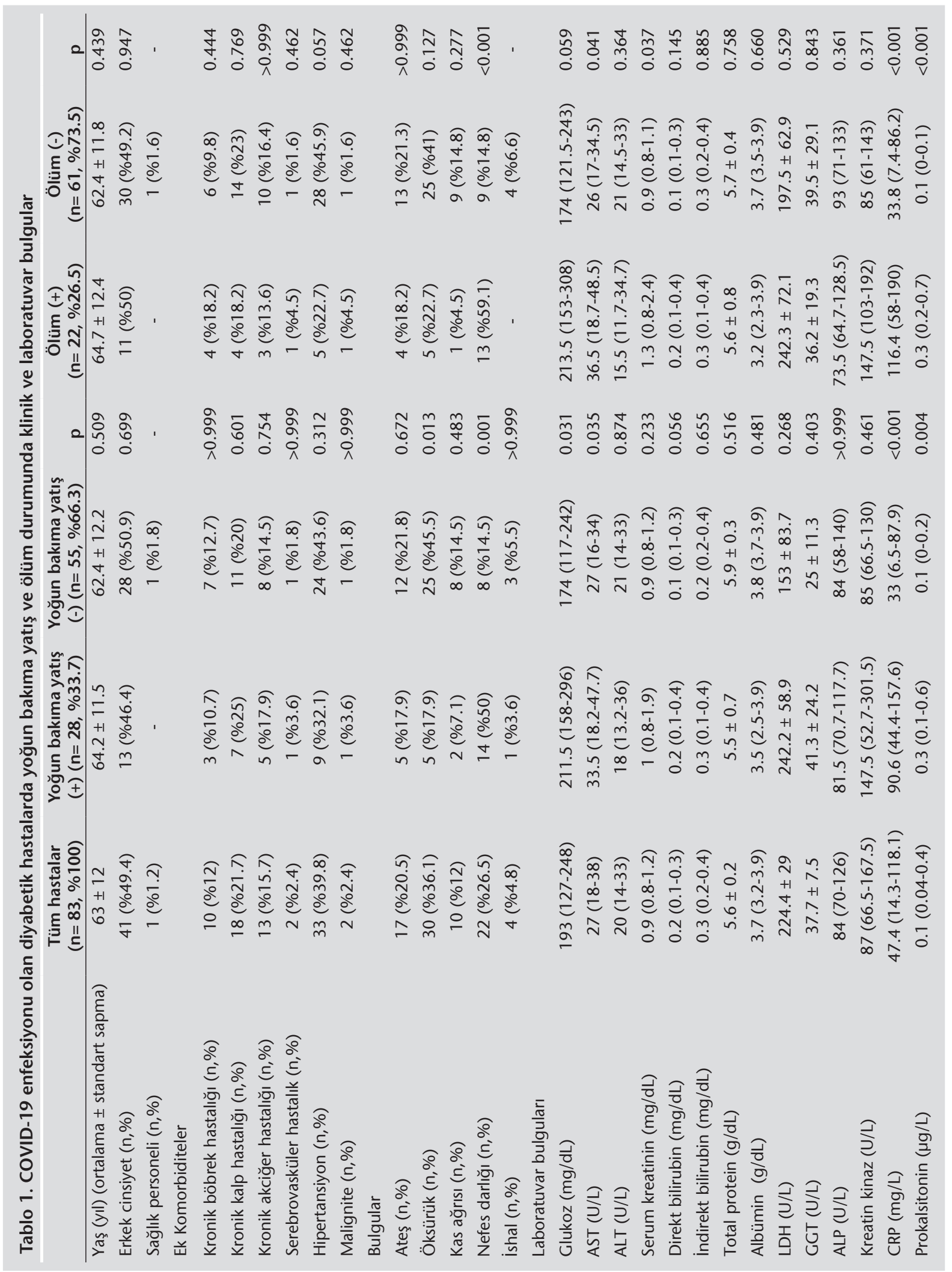




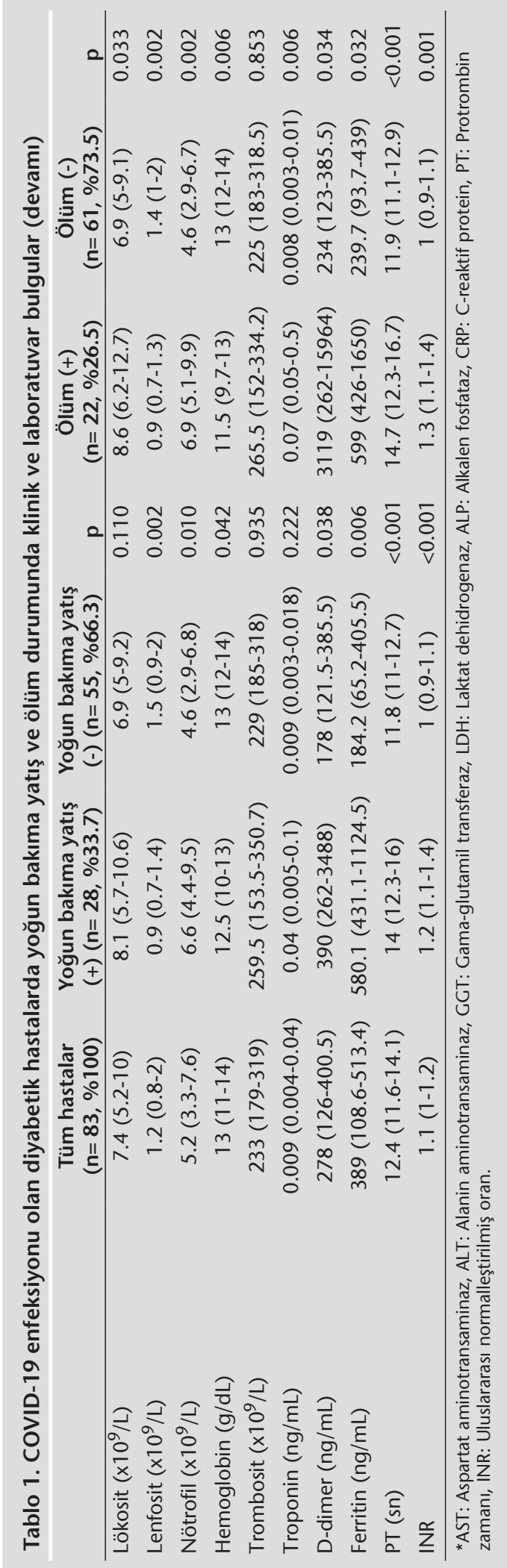

deki rolü ile ilgili bilgiler kısıtlıdır. Calıșmamızda COVID-19 ile infekte diyabetik hastalarda eslik eden komorbid hastalıkların hem yoğun bakıma yatıs hem de mortalite gelișimi açısından anlamlı risk olușturmadığını gösterdik. Diyabetik hastalarda gelisen COVID-19 infeksiyonunda kötü gidis ile komorbiditeler arasındaki iliskiyi belirlemek adına yas ve ek risk faktörlerine göre düzeltilerek dizayn edilecek ileriye yönelik çalıșmalar daha aydınlatıcı olacaktır.

COVID-19 infeksiyonunda laboratuvar bulguları genellikle tanısal değildir ancak klinik seyir ve komplikasyonları öngörmede fayda sağlayabilir ${ }^{[16]}$. Tam kan sayımı genellikle normal olmakla birlikte lökopeni, lenfopeni, trombositopeni ve eșlik eden CRP yüksekliği görülebilmektedir. Ağır COVID-19 hastalığında lökositoz, lenfopeni, anemi, trombositopeninin daha sı görüldüğü; kreatin kinaz, miyoglobin, kreatin fosfokinaz, AST, ALT, LDH, prokalsitonin, ferritin, troponin, D-dimer, PT ve INR seviyelerinin daha yüksek seyredebildiği bildirilmiștir ${ }^{[16,17]}$. İzleminde yoğun bakım takibi gereken ve ölen hastalarımızda kan sekerinin daha yüksek seyrettiği, böbrek ve karaciğer fonksiyonlarının, koagülasyon ve infeksiyon parametrelerinin daha bozuk seyrettiğini gösterdik. Laboratuvar parametrelerinin normalden sapma derecesi, sistemik inflamatuvar yanıtın siddetinin göstergesi olabileceğinden ağır COVID-19 hastalığını belirlemede önemli bir objektif değerlendirme aracı olabilir.

Sonuc olarak, hastanede yatarak izlenen COVID-19 infeksiyonu olan diyabetik hastalarda yoğun bakıma yatıș ve mortalite oranları yüksek seyretmektedir. Muhtemelen siddetli inflamatuvar yanıta bağlı olarak ağır COVID-19 geçiren diyabetik hastaların laboratuvar parametrelerinde belirgin bozukluk görülmektedir. COVID-19 yönetiminde özellikle diyabetik hastalarda yakın takip gerekmektedir.

\section{ETIK KURUL ONAYI}

Çalıșma için İzmir Katip Celebi Üniversitesi Girișimsel Olmayan Klinik Araștırmalar Etik Kurulundan onay alındı (Tarih: 27.05.2021, Karar no: 0275).

\section{ÇIKAR ÇATIŞMASI}

Yazarlar bu makale ile ilgili herhangi bir çkar catıșması bildirmemișlerdir. 


\section{YAZAR KATKISI}

Anafikir/Planlama: PS, TD

Analiz/Yorum: PS, TD

Veri sağlama: PS, TD

Yazım: PS

Gözden Geçirme ve Düzeltme: TD

Onaylama: PS, TD

\section{KAYNAKLAR}

1. Ejaz $H$, Alsrhani A, Zafar A, Javed $H$, Junaid K, Abdalla $A E$, et al. COVID-19 and comorbidities: Deleterious impact on in fected patients. J Infect Public Health 2020;13(12):1833-9.

2. Cuschieri S, Grech S. COVID-19 and diabetes: The why, the what and the how. I Diabetes Complications 2020;34(9):107637.

3. Guo W, Li M, Dong Y, Zhou H, Zhang Z, Tian C, et al. Diabetes is a risk factor for the progression and prognosis of COVID-19. Diabetes Metab Res Rev 2020:e3319.

4. Peric S, Stulnig TM. Diabetes and COVID-19: Disease-management-people. Wien Klin Wochenschr 2020;132(1314):356-1.

5. Guan WJ, Ni ZY, Hu Y, Liang WH, Ou CQ, He JX, et al; China Medical Treatment Expert Group for Covid-19. Clinical Characteristics of Coronavirus Disease 2019 in China. N Engl J Med 2020;382(18):1708-20.

6. Fadini GP, Morieri ML, Longato E, Avogaro A. Prevalence and impact of diabetes among people infected with SARS CoV-2. J Endocrinol Invest 2020;43(6):867-9.

7. Wang D, Hu B, Hu C, Zhu F, Liu X, Zhang J, et al. Clinical characteristics of 138 hospitalized patients with 2019 novel Coronavirus-infected pneumonia in Wuhan, China. JAMA 2020;323(11):1061-9.

8. Singh AK, Gupta R, Ghosh A, Misra A. Diabetes in COVID-19: Prevalence, pathophysiology, prognosis and practical considerations. Diabetes Metab Syndr 2020;14(4):303 10.

9. T.C. Sağıı Bakanlığı. Erişim tarihi: 17.06.2021. Available from: https://covid19.saglik.gov.tr/TR-66301/covid-19-rehberi.html.
10. World Health Organization (WHO) Coronavirus disease 2019. Erişim tarihi: 26.09.2021. Available from: https:// www.who.int/emergencies/diseases/novel-coronavirus-2019.

11. Guan WJ, Liang WH, Zhao Y, Liang HR, Chen ZS, Li YM, et al; China Medical Treatment Expert Group for COVID-19. Comorbidity and its impact on 1590 patients with COVID-19 in China: a nationwide analysis. Eur Respir J 2020;55(5):2000547.

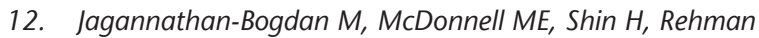
Q, Hasturk H, Apovian CM, et al. Elevated proinflammatory cytokine production by a skewed $T$ cell compartment requires monocytes and promotes inflammation in type 2 diabetes. J Immunol 2011;186(2):1162-72.

13. Wang TT. IgG FC Glycosylation in Human Immunity. Curr Top Microbiol Immunol 2019;423:63-75.

14. Yan $Y$, Yang $Y$, Wang $F$, Ren $H$, Zhang S, Shi $X$, et al. Clinical characteristics and outcomes of patients with severe Covid-19 with diabetes. BMJ Open Diabetes Res Care 2020;8(1):e001343.

15. Zhou F, Yu T, Du R, Fan G, Liu Y, Liu Z, Xiang J, Wang Y, Song B, Gu X, Guan L, Wei Y, Li H, Wu X, Xu J, Tu S, Zhang Y, Chen $\mathrm{H}, \mathrm{CaO} B$. Clinical course and risk factors for mortality of adult inpatients with COVID-19 in Wuhan, China: a retrospective cohort study. Lancet. 2020;395(10229):105462.

16. Mohamadian M, Chiti H, Shoghli A, Biglari S, Parsamanesh N, Esmaeilzadeh A. COVID-19: Virology, biology and novel laboratory diagnosis. J Gene Med 2021;23(2):e3303.

17. Zhou F, Yu T, Du R, Fan G, Liu Y, Liu Z, et al. Clinical course and risk factors for mortality of adult inpatients with COVID-19 in Wuhan, China: a retrospective cohort study. Lancet 2020;395(10229):1054-62.

\section{Yazıșma Adresi/Address for Correspondence}

Dr. Pınar ŞEN

İzmir Katip Celebi Üniversitesi

Atatürk Eğitim ve Araștırma Hastanesi,

İneksiyon Hastalıkları ve

Klinik Mikrobiyoloji Kliniği

İzmir-Türkiye

E-posta: pinarozdemirsen@gmail.com 